\title{
PENGEMBANGAN MEDIA PEMBELAJARAN KOSAKATA BAHASA INGGRIS BERBANTUAN KOMPUTER UNTUK SISWA SMP KELAS VII
}

\author{
Bastani ${ }^{1)}$, Pujiati Suyata ${ }^{2)}$ \\ SMP Negeri 1 Loksado Hulu Sungai Selatan Kalsel ${ }^{1)}$, Universitas Negeri Yogyakarta ${ }^{2)}$ \\ muhammadbastani@yahoo.com ${ }^{1)}$, pujiati_suyata@uny.ac.id ${ }^{2)}$
}

\begin{abstract}
Abstrak
Penelitian ini bertujuan: (1) menghasilkan media pembelajaran kosakata bahasa Inggris berbantuan komputer untuk siswa SMP kelas VII; dan (2) mengetahui kelayakan media pada aspek materi, pemrograman, dan tampilan. Penelitian ini adalah penelitian dan pengembangan dengan menggunakan model pengembangan Borg \& Gall dan Alessi \& Trollip's yang telah dimodifikasi. Penelitian ini dilaksanakan melalui tiga tahap, yaitu perencanaan, desain, dan pengembangan. Tahap perencanaan meliputi penetapan tujuan dan penganalisisan kebutuhan. Tahap desain meliputi penyelenggaraan focus group discussion, pembuatan flowchart, storyboard, penyiapan materi, dan bahan pendukung. Tahap pengembangan meliputi pembuatan aplikasi berdasarkan flowchart dan storyboard, validasi ahli dan validasi pengguna. Instrumen penelitian yang digunakan adalah kuesioner/angket dan tes. Hasil penelitian dan pengembangan ini adalah: (1) produk media pembelajaran kosakata bahasa Inggris berbantuan komputer dalam bentuk CD pembelajaran dan print out produk; dan (2) kelayakan media ditinjau dari aspek materi termasuk kriteria sangat layak dengan rata-rata skor 4,47 pada skala lima, aspek pemrograman termasuk kriteria sangat layak dengan ratarata skor 4,21 dan aspek tampilan termasuk kriteria sangat layak dengan rata-rata skor 4,44.
\end{abstract}

Kata kunci: pengembangan, media pembelajaran, kosakata, pembelajaran berbantuan komputer.

\begin{abstract}
The aims of this research are: (1) to produce the computer-assisted instructional media of English vocabulary for grade VII of junior high school students; and (2) reveal the media quality on the material, programming, and display aspects. This research and development uses the Borg \& Gall and Alessi \& Trollip's model that have been modified, conducted through three phases: planning, design, and development. The planning phase includes setting goals and needs analysis. The design phase includes conducting focus group discussion, creating a flowchart, storyboards, preparing materials, and supporting materials. The phase of development includes creating applications based flowchart and storyboards, experts validation and user validation. The research instruments were questionnaires and tests. The quality of media can be seen from the results of the experts validation, users validation data, and the increased of the minimal standard of learning mastery (KKM) achievement. The results of the research and development are: (1) the computer-assisted instructional media of English vocabulary in instructional CD and print out of product; and (2) the quality of media on learning material aspect is in the very good category with an average score of 4.47 in scale of five, the programming aspect is in the very good category with an average score of 4.21 and the display is in the very good category with an average score of 4.44 .
\end{abstract}

Keywords: development, instructiona media,vocabulary, computer-assisted instructional. 


\section{PENDAHULUAN}

Berdasarkan Peraturan Menteri Pendidikan Nasional Republik Indonesia Nomor 22 Tahun 2006 halaman 277 tentang Standar Isi, pemerintah menetapkan bahasa Inggris sebagai salah satu mata pelajaran yang wajib diajarkan di tingkat sekolah menengah. Pembelajaran Bahasa Inggris di SMP ditargetkan agar peserta didik dapat mencapai tingkat functional yakni berbahasa untuk menyelesaikan masalah seharihari.

Agar peserta didik bisa berbahasa Inggris diperlukan penguasaan kosakata yang cukup. Kosakata merupakan hal yang penting dan sangat berpengaruh pada semua aspek keterampilan berbahasa, termasuk keterampilan membaca. Peserta didik akan lebih mudah memahami sebuah teks jika tingkat penguasaan kosakata mereka tinggi, dan sebaliknya mereka kesulitan memahami teks dan cepat bosan membaca jika hanya sedikit kosakata yang mereka ketahui. Tanpa kosakata suatu bahasa tidak akan berfungsi sebagaimana mestinya, struktur dan tata bahasa tidak bisa digunakan. Tanpa struktur dan tata bahasa seseorang masih bisa sedikit menyampaikan pesan, tapi tanpa kosakata tak ada pesan yang bisa disampaikan. Kualitas berbahasa peserta didik dipengaruhi oleh kuantitas dan kualitas kosakata. Mengingat pentingnya kosakata dalam berbahasa maka pembelajaran kosakata perlu dilakukan pada pembelajaran bahasa Inggris.

Keterampilan membaca merupakan keterampilan yang mendapat perhatian lebih dalam ujian nasional, dibandingkan dengan tiga keterampilan lainnya. Aspek keterampilan membaca mendominasi dalam soal UN tersebut. Agar peserta didik berhasil ujian nasional, mereka harus lebih terampil memahami teks. Dalam memahami teks, penguasaan kosakata sangat diperlukan. Tarigan (1993, p.2) mengatakan bahwa keterampilan berbahasa seseorang tergantung pada kualitas dan kuantitas kosakata yang dimilikinya. Semakin tinggi penguasaan kosakata semakin besar kemungkinan terampil dalam memahami teks. Karena itu media pembelajaran kosakata ini lebih memfokuskan pada kegiatan pembelajaran kosakata untuk memahami teks.

Berdasarkan hasil prasurvei yang dilakukan oleh peneliti pada sekolah-sekolah menengah pertama di Kalimantan Selatan menunjukkan bahwa penguasaan kosakata bahasa Inggris peserta didik masih rendah. Untuk meningkat- kan penguasaan kosakata dalam pembelajaran bahasa Inggris, dukungan media pembelajaran sangat diperlukan. Tanpa bantuan sarana penyampai pesan atau media, komunikasi tidak akan berjalan. Sayangnya media pembelajaran yang tersedia di sekolah sangat terbatas, guru terpaksa hanya menggunakan media pembelajaran yang tersedia. Guru kurang kreatif mengembangkan media pembelajaran, padahal sebagai seorang profesional, guru dituntut untuk bisa mengembangkan media pembelajaran.

Media pembelajaran sangat sulit diperoleh di Kabupaten Hulu Sungai Selatan, apalagi media yang berupa $C D$ pembelajaran. Kebanyakan CD yang ada di pasaran materinya terlalu umum, tidak mengacu pada kurikulum sekolah, sehingga tidak layak kalau digunakan sebagai media pembelajaran. Isi CD hanya memuat materi untuk listening, monoton dan tidak interaktif, kurang menarik dan kurang memotivasi, sehingga peserta didik cepat bosan dalam belajar bahasa Inggris.

Berdasarkan hal tesebut, pengembangan media pembelajaran perlu dilakukan oleh guru. Media pembelajaran yang tepat untuk dikembangkan adalah media pembelajaran berbantuan komputer karena media ini menggunakan teks, gambar, suara dan animasi menarik yang dapat memotivasi peserta didik dalam belajar bahasa Inggris, sehingga dapat meningkatkan penguasaan kosakata bahasa Inggris siswa.

Penelitian ini dibatasi pada permasalahan belum adanya media berupa CD pembelajaran bahasa Inggris yang dirancang sesuai kurikulum, dan layak digunakan dalam pembelajaran bahasa Inggris. Oleh karena itu, penelitian ini difokuskan pada pengembangan media berupa CD pembelajaran kosakata yang relevan dan mencirikan jenis teks yang dipelajarari siswa SMP kelas VII sesuai dengan kurikulum, dan layak digunakan dalam pembelajaran kosakata bahasa Inggris. Kosakata yang dimuat pada pengembangan ini adalah kosakata yang berhubungan dengan teks deskriptif. Siswa SMP kelas VII diajarkan kosakata bahasa Inggris agar mereka sejak dini secara bertahap dapat mengembangkan kosakata bahasa Inggris, dengan penguasaan kosakata yang memadai sejak kelas VII peserta didik tidak akan banyak mengalami kesulitan dalam memahami teks pada saat ujian nasional.

\section{Media Pembelajaran Berbantuan Komputer}

Menurut Indriana (2011, p.99) media pembelajaran berbantuan komputer adalah sistem-sistem komputer yang dapat menyampaikan 
pembelajaran secara langsung kepada siswa melalui cara berinteraksi dengan mata pelajaran yang diprogramkan ke dalam sistem. Komputer mengambil lebih banyak bagian dari pekerjaan seorang guru, seluruh bahan dapat dipresentasikan dengan komputer. Egbert (2005, p.4) mengatakan bahwa pembelajaran bahasa berbantuan komputer adalah siswa belajar bahasa dalam beberapa konteks menggunakan, melalui dan berhubungan dengan teknologi komputer. Pendapat serupa juga dikemukakan oleh Tchounikine (2011, p.4) bahwa pembelajaran berbantuan komputer adalah sesuatu yang dimanipulasi menggunakan software dengan tujuan pendidikan.

Constantinescu (2007, p.2) menyatakan “... computer-based systems that use various types of content, such as text, audio, video, graphics, animation, and interactivity". Maksudnya media berbantuan komputer adalah sistem berbasis komputer yang menggunakan berbagai jenis isi seperti teks, audio, video, grafik, animasi, dan interaktivitas. Suyanto (2003, p.21) mengemukakan bahwa berbantuan komputer adalah pemanfaatan komputer untuk membuat dan menggabungkan teks-teks, grafik, audio, Gambar bergerak (video dan animasi) dengan menggabungkan link atau tool yang memungkinkan pemakai melakukan navigasi, berinteraksi, berkreasi, dan berkomunikasi.

Berdasarkan pendapat tersebut, dapat didefinisikan media pembelajaran berbantuan komputer adalah media yang menggabungkan dua unsur atau lebih media yang terdiri dari teks, grafik, gambar, foto, audio, video dan animasi yang dimanipulasi secara digital menggunakan komputer yang digunakan dalam kegiatan pembelajaran.

Media sebagai bagian yang tidak terpisahkan dari pembelajaran, maka dalam memilih media yang tepat untuk membantu tugas sebagai guru perlu diperhatikan beberapa kriteria. Kriteria media pembelajaran yang baik menurut Sudjana dan Rivai (2010, pp.4-5), adalah (1) ketepatan dengan tujuan pengajaran, (2) dukungan terhadap isi bahan pelajaran, (3) kemudahan memperoleh media, (4) keterampilan guru dalam menggunakannya, (5) tersedia waktu untuk menggunakannya, dan (6) sesuai dengan taraf berfikir siswa. Menurut Chomsin dan Jasmadi (2008, p.72) kriteria media pembelajaran dari aspek materi yaitu: (1) Terdapat rumusan tujuan kompetensi yang jelas, (2) menekankan pada pencapaian kompetensi yang sesuai, (3) terdapat panduan belajar yang mudah digunakan, (4) memuat pengetahuan sesuai dengan unit kompetensi, (5) memuat keterampilan sesuai dengan unit kompetensi, (6) memuat sikap yang jelas untuk diperagakan, (7) bahasa mudah dimengerti, (8) tugas dan latihan cukup untuk membantu mencapai kompetensi, (9) tugas dan latihan sesuai dengan unit kompetensi, (10) materi pembelajaran sesuai dengan tingkat peserta didik, (11) memungkinkan peserta didik melakukan inisiatif sendiri dalam belajarnya, (12) memungkinkan peserta didik belajar secara mandiri, (13) materi diorganisasikan dengan susunan yang sistematis, (14) terdapat bagian assessment (pengujian), (15) instrumen assessment mudah dimengerti, (16) instruksi pada assessment mudah dimengerti, (16) memungkinkan peserta didik melakukan assessment sendiri.

Kriteria program pembelajaran berbantuan komputer menurut Arsyad (2011, p.183) adalah sebagai berikut: (1) terfokus dengan jelas pada tujuan, (2) interaktif terus-menerus, (3) bercabang untuk menyesuaikan dengan tingkat kemampuan siswa, (4) relevan dengan tujan kurikuler dan sasaran belajar, (5) format penyajiannya memotivasi, (6) terbukti efektif (yaitu dengan uji coba di lapangan), (7) sajian gambar/ grafik yang sesuai, (8) petunjuknya sederhana dan lengkap, (9) memberi penguatan positif, (10) dapat digunakan lagi.

Menurut Wahono (2006) kriteria media pembelajaran pada aspek desain pembelajaran adalah sebagai berikut: (1) Kejelasan tujuan pembelajaran (rumusan, realistis), (2) relevansi tujuan pembelajaran dengan SK/ KD/Kurikulum, (3) cakupan dan kedalaman tujuan pembelajaran, (4) ketepatan penggunaan strategi pembelajaran, (5) interaktivitas, (6) pemberian motivasi belajar, (7) kontekstualitas dan aktualitas, (8) kelengkapan dan kelayakan bahan bantuan belajar, (9) kesesuaian materi dengan tujuan pembelajaran, (10) kedalaman materi, (11) kemudahan untuk dipahami, (12) sistematis, runut, alur logika jelas, (13) kejelasan uraian, pembahasan, contoh, simulasi, latihan, (14) konsistensi evaluasi dengan tujuan pembelajaran, (15) ketepatan dan ketetapan alat evaluasi, (16) pemberian umpan balik terhadap hasil evaluasi.

Mishra dan Sharma (2005, pp.115-116) menyatakan educational software yang baik adalah software yang didesain sesuai dengan tiga prinsip berikut: (1) software komputer dan ICT secara umum seharusnya sebagai alat untuk memudahkan pengguna, (2) antarmuka harus mampu memberikan kepada pengguna mengekspresikan kemampuan dirinya, (3) pengetahu- 
an atau materi pendidikan harus disampaikan dengan berbagai cara. Lee dan Owens (2004, pp.181-182) mengemukakan bahwa software pembelajaran harus: ada komponen navigasi yang memuat tombol "lanjut", "kembali", "glossary" dan "bantuan"; model pengujian kemampuan harus bervariasi (benar-salah, menjodohkan dengan drag kata, pilihan ganda, jawaban singkat) dan ada feedback; ada bagian tes untuk mengetahui perkembangan pembelajaran dan disertai penskoran.

\section{Kosakata}

Kosakata (vocabulary) adalah kumpulan kata, khazanah kata, leksikon (Kridalaksana, 2008, p.137). Kridalaksana menekankan pada kosakata sebagai komponen bahasa yang memuat semua informasi tentang makna dan pemakaian kata dalam bahasa. Hadumod (1996, p.1268) mendefinisikan kosakata adalah sejumlah kata dalam suatu bahasa. Hornby (1994, p.959) menekankan pada kosakata sebagai pembentuk suatu bahasa. Kosakata adalah komponen kecakapan berbahasa dan merupakan dasar bagaimana seseorang dapat menyimak, berbicara, membaca, dan menulis dengan baik.

Richard dan Renandya (2002, p.255) mengemukakan bahwa kosakata merupakan komponen penting kecakapan berbahasa dan merupakan dasar bagaimana peserta didik dapat berbicara, menyimak, membaca dan menulis. Tanpa penguasaan kosakata yang luas dan adanya strategi untuk memperoleh kosakata baru, peserta didik berpotensi mengalami kendala, terutama kesempatan menggunakan bahasa di antara mereka seperti mendengarkan radio, menyimak pembicaraan native speaker, menggunakan dalam berbagai konteks seperti membaca atau menonton televisi.

Rivers dalam Nunan (1991, p.11) menyatakan bahwa kosakata merupakan hal yang penting agar dapat menggunakan bahasa kedua (second language). Tanpa kosakata yang luas, seseorang tidak akan dapat menggunakan struktur dan fungsi bahasa dalam komunikasi secara komprehensif. Tarigan (1986, p.2) menyatakan bahwa kualitas berbahasa seseorang tergantung pada kualitas kosakata yang dimiliki.

Nation dalam Richads \& Renandya (2002, p.267) mengatakan bahwa pengajaran yang fokus pada penguasaan kosakata merupakan esensi dalam pengajaran bahasa. Thornbury (2002, p.15) menyatakan bahwa penguasaan kosakata pada tingkat dasar adalah tahu bentuk dan artinya. McCharty (1992, p.2) mendifinisi- kan menguasai kosakata tidak hanya tahu arti dari kata itu, tetapi juga harus tahu hal yang berhubungan dengan kata, karakteristik tata bahasa, dan pelafalan kata. Kosakata suatu bahasa itu sangat luas dan proses penguasaan kosakata membutuhkan waktu yang panjang atau lama, bahkan untuk menguasai kosakata bahasa ibu. Sebagaimana dinyatakan oleh Wakely (2003, p.1) "The vocabulary of any language is huge and its acquisition takes time, even for a native speaker". Meister dan Honeyfield dalam Prayitno (1990, p. 6) mengemukakan bahwa seseorang dapat dikatakan menguasai sebuah kata apabila ia telah menunguasai empat hal, yakni lafal, ejaan, makna dan bagaimana menggunakannya. Pemahaman dan penguasaan kosakata yang dipelajari tidak lepas dari konteks makna yang ada. Kata yang diperoleh tidak akan berarti apabila sekedar kata lepas dan tidak disertakan kebermaknaannya.

Penguasaan kosakata pada penelitian ini dibatasi pada penguasaaan kosakata dalam memahami makna teks tulis esei pendek sangat sederhana berbentuk descriptive yang mendeskripsikan tentang orang dan binatang. Siswa dapat menentukan gambaran umum, informasi rinci tersurat, informasi rinci tersirat, informasi tertentu, makna kata, frase, kalimat dari teks descriptive.

Tarigan (1989, p.23) mengemukakan bahwa penguasaan kosakata dapat dilakukan melalui (1) ujian sebagai pengajaran; (2) petunjuk konteks; (3) sinonim antonym; (4) asal-usul kata; (5) prefiks; (6) sufiks; (7) akar kata; (8) ucapan dan ejaan; (9) semantik; (10) majas; (11) sastra dan pengembangan kosakata; (12) penggunaan kamus; (13) permainan kata. Ma dan Kelly (2006, p.16) mengatakan bahwa kosakata itu bisa dikuasai secara eksplisit dan implisit. Nation (2002, pp.11-12) mengidentifikasi sepuluh teknik untuk menguasai kosakata, yaitu: (1) memperoleh penjelasan tentang makna kata dan penggunaan kata tersebut; (2) mempelajari kata melalui kartu kata; (3) menyimak terjemahan kata; (4) menebak makna kata berdasarkan konteks; (5) melakukan kolokasi menjodohkan; (6) mencari makna kata dalam kamus; (7) mencari kata sejenis; (8) menanyakan tentang makna kata yang sulit; (9) mengungkapkan kata-kata yang telah diketahui; dan (10) menulis kata-kata sulit setelah menyimak cerita.

Dengan demikian, untuk menguasai kosakata peserta didik tidak hanya mempelajari arti kata tersebut melalui kamus saja. Salah satu cara yang dianggap paling baik dan memiliki du- 
kungan perangkat yang lengkap adalah belajar kosakata berbantuan komputer dengan menggunakan software yang dirancang secara khusus dengan berbagai kegiatan pembelajaran yang interaktif untuk pembelajaran kosakata bahasa Inggris.

\section{Pembelajaran Kosakata Berbantuan Komputer}

Kemajuan media komputer memberikan beberapa kelebihan untuk kegiatan produksi audio visual. Menurut Cilesiz (2009, p.235) komputer dapat digunakan dalam kegiatan belajar mengajar dalam melaksanakan kurikulum, termasuk pembelajaran kosakata. Mayer (2001, pp.275-276) mensyaratkan agar lebih efektif dalam mempelajari kosakata dengan bantuan komputer ini harus: (1) keterdekatan ruang, saat kata-kata dan gambar-gambar terkait disajikan secara berdekatan daripada secara berjauhan di halaman atau layar, (2) keterdekatan waktu, saat kata-kata dan gambar-gambar terkait disajikan secara simultan daripada secara suksesif dalam waktu, (3) koherensi, saat kata-kata, suara-suara dan gambar-gambar tambahan diminimaliskan, (4) modalitas, saat kata-kata disajikan sebagai ucapan daripada sebagai teks dalam presentasi multimedia, dan (5) redudansi, saat kata-kata disajikan sebagai ucapan daripada sebagai ucapan sekaligus teks dalam presentasi multimedia. (Mayer, 2001, pp.275-276)

Pembelajaran dengan berbantuan komputer ini umumnya dikenal dengan ComputerAssisted Instruction (CAI). Menurut Azhar (2011, p.31), aplikasi tersebut apabila dilihat dari cara penyajian dan tujuan yang ingin dicapai, meliputi: (1) tutorial (penyajian materi pelajaran secara bertahap), (2) drills and practice (latihan untuk membantu siswa menguasai materi yang telah dipelajari sebelumnya), (3) permainan dan simulasi (latihan mengaplikasikan pengetahuan dan keterampilan yang baru dipelajari), (4) basis data (sumber yang dapat membantu siswa menambah informasi dan pengetahuannya sesuai keinginan masing-masing). Pendapat serupa dikemukakan oleh Heinich, et.al (1996), bentuk interaksi yang dapat diaplikasikan: (1) praktek dan latihan (drill \& practice), (2) tutorial, (3) permainan (games), (4) simulasi (simulation), (5) penemuan (discovery), (6) pemecahan masalah (problem solving). Komputer dalam pembelajaran bahasa memiliki tiga fungsi, yaitu sebagai alat, tutor, dan tutee. Komputer sebagai alat dapat digunakan sebagai program untuk memproses kata-kata seperti menulis cerita, puisi, atau jenis karangan lainnya. Komputer sebagai tutor atau dikenal dengan istilah $C A I$ dapat berfungsi sebagai alat bantu atau media pengajaran. Komputer sebagai tutee dapat digunakan dalam mempelajari bahasa komputer dan pemrograman komputer. Constantinescu (2007, p.4) menyebutkan empat prinsip mengajar dalam pembelajaran ba-hasa berbantuan komputer untuk pengembangan kosakata, yaitu : (1) guru harus memperhatikan ketersediaan alat-alat mengajar, (2) guru harus memberi penjelasan dalam bentuk teks dengan menggunakan multimedia, (3) guru harus mengetahui jenis-jenis materi online dalam pembelajaran bahasa Inggris karena tidak semua materi tersebut dapat digunakan di dalam kelas, (4) guru harus menggunakan metode yang sesuai dan memanfaatkan multimedia dengan baik.

Jadi komputer bisa digunakan sebagai media dalam bermacam-macam pembelajaran, termasuk pembelajaran kosakata bahasa Inggris. Hal ini tergantung kecakapan pendesain dan pengembang, berbagai bentuk penyajian bisa dilakukan misalnya dalam bentuk permainan (games), drill dan practice, mengajarkan konsep-konsep abstrak yang kemudian dikonkritkan dalam bentuk visual dan audio yang dianimasikan, agar pembelajaran menjadi lebih menarik bagi siswa.

\section{METODE PENELITIAN}

\section{Jenis Penelitian}

Jenis penelitian ini adalah penelitian dan pengembangan (research and development).

\section{Waktu dan Tempat Penelitian}

Waktu penelitian atau waktu uji coba terhadap produk terbagi menjadi tiga tahap. Tahap pertama, uji coba perorangan dilakukan pada tanggal 10 Desember 2012. Tahap kedua, uji coba kelompok kecil dilakukan pada tanggal 11 Desember 2012. Tahap ketiga uji coba lapangan, dilakukan pada tanggal 13, 15, 24, dan 26 Desember 2012. Tempat uji coba tersebut adalah di laboratorium komputer SMP Negeri 1 Kandangan Kabupaten Hulu Sungai Selatan.

\section{Prosedur}

Prosedur penelitian pengembangan ini memodifikasi model pengembangan Borg \& Gall (1983) dan Alessi \& Trollip's (2001). Model modifikasi ini secara garis besar dikelompokan menjadi tiga bagian seperti pada model Alessi \& Trollip's yaitu perencanaan, desain, 
dan pengembangan. Kemudian langkah-langkah pengembangan yang lebih detail mengadopsi langkah-langkah yang ada pada model pengembangan Borg \& Gall dan menambahkan langkah-langkah kegiatan yang mendukung penelitian, seperti fokus group discussion. Model modifikasi tersebut dapat dilihat pada Gambar 1. berikut ini.

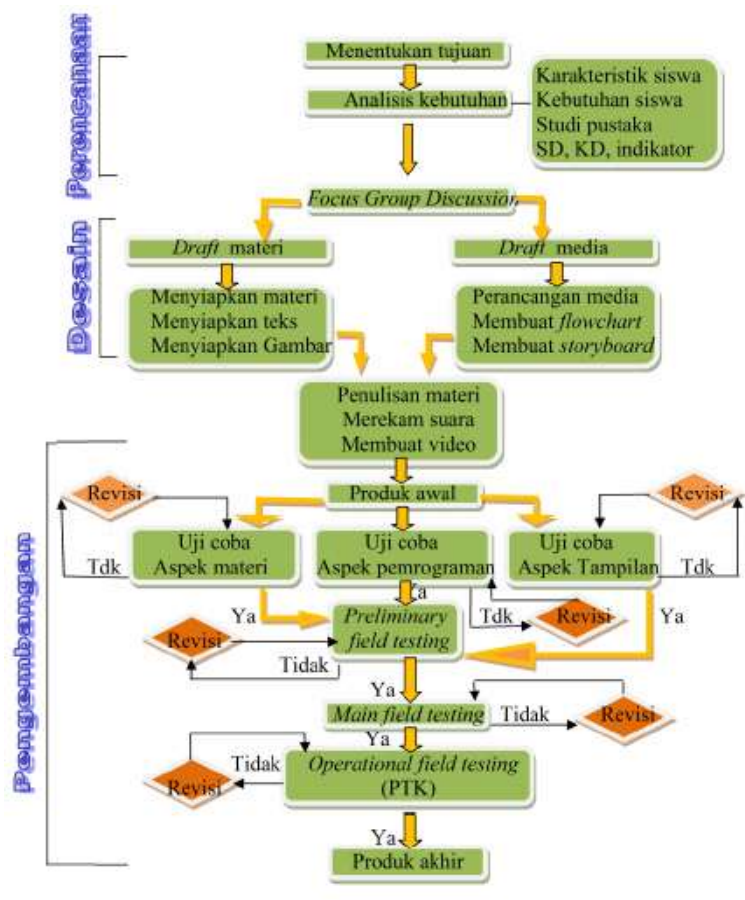

Gambar 1. Prosedur Pengembangan Media pembelajaran Modifikasi dari Model Borg \& Gall (1983) dan Alessi \& Trollip's (2001)

Secara garis besar penelitian ini dilakukan melalui tiga tahap, yaitu tahap perencanaan, desain dan pengembangan. Tahap pertama perencanaan, yaitu menentukan tujuan penelitian dan menganalisis kebutuhan. Penelitian pengembangan ini bertujuan mengembangkan sebuah media pembelajaran kosakata bahasa Inggris berbantuan komputer untuk siswa SMP kelas VII. Analisis kebutuhan dilakukan dengan prasurvei dan studi pustaka dengan mempelajari kurikulum yang digunakan untuk menetapkan SK, KD, dan indikator pembelajaran. Tahap kedua desain, yaitu melakukan Focus Group Discussion, membuat draft materi, menyiapkan materi, menyiapkan teks, menyiapkan gambar, dan membuat draft media; membuat flowchart dan storyboard. Tahap ketiga pengembangan, pada tahap ini dimulai dengan mengembangkan materi pembelajaran berdasarkan $\mathrm{SD}, \mathrm{KD}$ dan indikator, merekam suara, membuat video dan membuat produk awal berdasarkan flowchart dan storyboard yang ada. Secara umum content dari CD pembelajaran ini adalah sebagai berikut: halaman intro/pembuka, menu utama yang terdiri dari halaman pendahuluan, halaman petunjuk, halaman kompetensi, halaman materi, halaman profil pengembang.

Produk direvisi berulang kali: (1) setelah diuji coba oleh guru, diberi komentar dan saran kemudian produk direvisi, (2) produk diuji coba kepada perorangan, diberi komentar dan saran kemudian produk direvisi, (3) produk diuji coba kepada kelompok kecil, diberi komentar dan saran kemudian produk direvisi, (4) produk diuji coba di lapangan, diberi komentar dan saran kemudian produk direvisi.

Validasi ahli dilakukan oleh tiga orang validator, yaitu satu orang ahli materi dan dua orang ahli media. Produk awal yang dibuat diuji oleh satu orang ahli materi yang menguji aspek materi, dua orang ahli media yang menguji aspek pemrograman dan tampilan. Ketiga ahli ini masing-masing memberikan komentar tentang kelemahan, kekurangan dari produk yang dibuat dan memberi saran untuk perbaikan produk. Kemudian produk direvisi berdasarkan saran dari para ahli tersebut.

Produk yang sudah direvisi diujicobakan lagi kepada pengguna, yaitu satu orang guru bahasa Inggris dan tiga orang siswa uji coba perorangan, sembilan orang siswa uji kelompok kecil, dan tiga puluh siswa uji coba lapangan. Produk direvisi berulang kali: (1) setelah diuji coba oleh guru, diberi komentar dan saran kemudian produk direvisi, (2) produk diuji coba kepada perorangan, diberi komentar dan saran kemudian produk direvisi, (3) produk diuji coba kepada kelompok kecil, diberi komentar dan saran kemudian produk direvisi, (4) produk diuji coba di lapangan, diberi komentar dan saran. Kemudian produk direvisi lagi dan menghasilkan sebuah produk akhir.

\section{Subjek Coba}

Subjek coba adalah siswa kelas VII SMP Negeri 1 Kandangan Kabupaten Hulu Sungai Selatan, terdiri dari tiga siswa uji coba perorangan, sembilan siswa uji coba kelompok kecil, tiga puluh siswa uji coba lapangan. Siswa tersebut mewakili kelompok siswa yang berkemampuan bahasa Inggris rendah, sedang, dan tinggi dengan proporsi yang sama.

Langkah-langkah untuk menentukan siswa subjek coba sebagai sasaran uji coba perorangan adalah sebagai berikut: (1) mengelompokkan siswa ke dalam kelompok dengan kemampuan bahasa Inggris tinggi, sedang, dan 
rendah. Siswa dikelompokkan ke dalam kelompok tinggi, sedang, dan rendah berdasarkan rentang nilai rapor mata pelajaran bahasa Inggris siswa semester sebelumnya dan hasil konsultasi dengan guru bahasa Inggris mereka. (2) memilih siswa secara acak. Setelah siswa dikelompokkan ke dalam kelompok tinggi, sedang, dan rendah, kemudian dilakukan pemilihan secara acak satu siswa dari masing-masing kelompok. Hasil dari pemilihan secara acak ini adalah tiga orang siswa yang terdiri dari satu orang siswa dari kelompok dengan tingkat kemampuan bahasa Inggris tinggi, satu orang siswa dari kelompok dengan tingkat kemampuan bahasa Inggris sedang, dan satu orang siswa dari kelompok dengan tingkat kemampuan bahasa Inggris rendah.

Langkah yang sama juga dilakukan untuk menentukan subjek coba kelompok kecil dan uji coba lapangan. Jumlah siswa yang diambil disesuaikan dengan keperluan.

\section{Data, Instrumen, dan Teknik Pengumpulan Data}

Data yang diperoleh dari penelitian dan pengembangan ini adalah data kuantitatif dan kualitatif. Data kuantitatif berupa skor penilaian dari ahli dan pengguna tentang kelayakan materi, pemrograman, tampilan. Data kualitatif berupa saran dan komentar dari validator digunakan sebagai acuan revisi produk.

Instrumen penelitian yang digunakan adalah kuesioner/angket dan tes. Kuesioner/ angket diisi oleh validator ahli sesuai bidang keahlian masing-masing. Validator pengguna memberikan penilaian terhadap aspek materi dan tampilan. Aspek yang dievaluasi meliputi aspek materi, pemrograman dan tampilan. Kisi-kisi instrumen penilaian dapat dilihat pada Tabel 1, Tabel 2, dan Tabel 3 berikut ini.

Tabel 1. Kisi-kisi Instrumen Penilaian untuk Ahli Materi Pembelajaran

\begin{tabular}{ll}
\hline Aspek & \multicolumn{1}{c}{ Indikator } \\
\hline & $\begin{array}{l}\text { Kejelasan tujuan pembelajaran (rumusan, } \\
\text { realistis) }\end{array}$ \\
\cline { 2 - 2 } $\begin{array}{l}\text { Kesesuaian tujuan pembelajaran dengan SK } \\
\text { Pembe- } \\
\text { lajaran }\end{array}$ & $\begin{array}{l}\text { Kesesuaian tujuan pembelajaran dengan } \\
\text { Kesesuaian materi dengan tujuan pembel- } \\
\end{array}$ \\
& $\begin{array}{l}\text { Kesaran } \\
\text { tingkat peserta didik }\end{array}$ \\
& $\begin{array}{l}\text { Materi diorganisasikan dengan susunan } \\
\text { yang sistematis }\end{array}$
\end{tabular}

\begin{tabular}{ll}
\hline Aspek & \multicolumn{1}{c}{ Indikator } \\
\hline & Bahasa mudah dimengerti \\
\hline Keterbacaan teks \\
\cline { 2 - 2 } Kejelasan gambar \\
$\frac{\text { Kesesuaian gambar dengan materi }}{\text { Tugas dan latihan cukup untuk membantu }}$ \\
mencapai kompetensi \\
$\begin{array}{l}\text { Tugas dan latihan sesuai dengan unit } \\
\text { kompetensi }\end{array}$ \\
$\begin{array}{l}\text { Memungkinkan peserta didik melakukan } \\
\text { inisiatif sendiri dalam belajarnya }\end{array}$ \\
$\begin{array}{l}\text { Memungkinkan peserta didik belajar secara } \\
\text { mandiri }\end{array}$ \\
$\frac{\text { Terdapat bagian assessment (pengujian) }}{\text { Instrumen assessment } \text { mudah dimengerti }}$ \\
$\begin{array}{l}\text { Petunjuk pada } \text { assessment } \text { mudah } \\
\text { dimengerti }\end{array}$ \\
$\begin{array}{l}\text { Konsistensi evaluasi dengan tujuan } \\
\text { pembelajaran }\end{array}$ \\
$\begin{array}{l}\text { Memungkinkan peserta didik melakukan } \\
\text { assessment sendiri }\end{array}$ \\
$\begin{array}{l}\text { Pemberian umpan balik terhadap hasil } \\
\text { evaluasi }\end{array}$
\end{tabular}

Tabel 2. Kisi-kisi Instrumen Penilaian untuk Ahli Media Pembelajaran pada Aspek Pemrograman

\begin{tabular}{ll}
\hline Aspek & \multicolumn{1}{c}{ Indikator } \\
\hline & $\begin{array}{l}\text { Program tidak terlalu besar/tidak terlalu } \\
\text { banyak menghabiskan space di } \\
\text { komputer. }\end{array}$ \\
\cline { 2 - 2 } Program berjalan dengan baik. \\
\cline { 2 - 2 } Pemro- \\
graman & $\begin{array}{l}\text { Program tidak mudah hang. } \\
\text { pengoperasian). }\end{array}$ \\
\cline { 2 - 2 } & $\begin{array}{l}\text { Desain dan tata letak navigasi. } \\
\text { Konsistensi bentuk navigasi }\end{array}$ \\
\cline { 2 - 2 } & $\begin{array}{l}\text { Ketepatan pemilihan jenis aplikasi/ } \\
\text { software/ tool untuk pengembangan. }\end{array}$ \\
\cline { 2 - 2 } $\begin{array}{l}\text { Media pembelajaran dapat diinstalasi/ } \\
\text { dijalankan di berbagai hardware dan } \\
\text { software yang ada. }\end{array}$ \\
$\begin{array}{l}\text { Pemaketan program media } \\
\text { pembelajaran terpadu dan mudah dalam } \\
\text { eksekusi. }\end{array}$ \\
\cline { 2 - 2 } $\begin{array}{l}\text { Media pembelajaran terpaket dengan } \\
\text { baik. }\end{array}$ \\
\hline
\end{tabular}




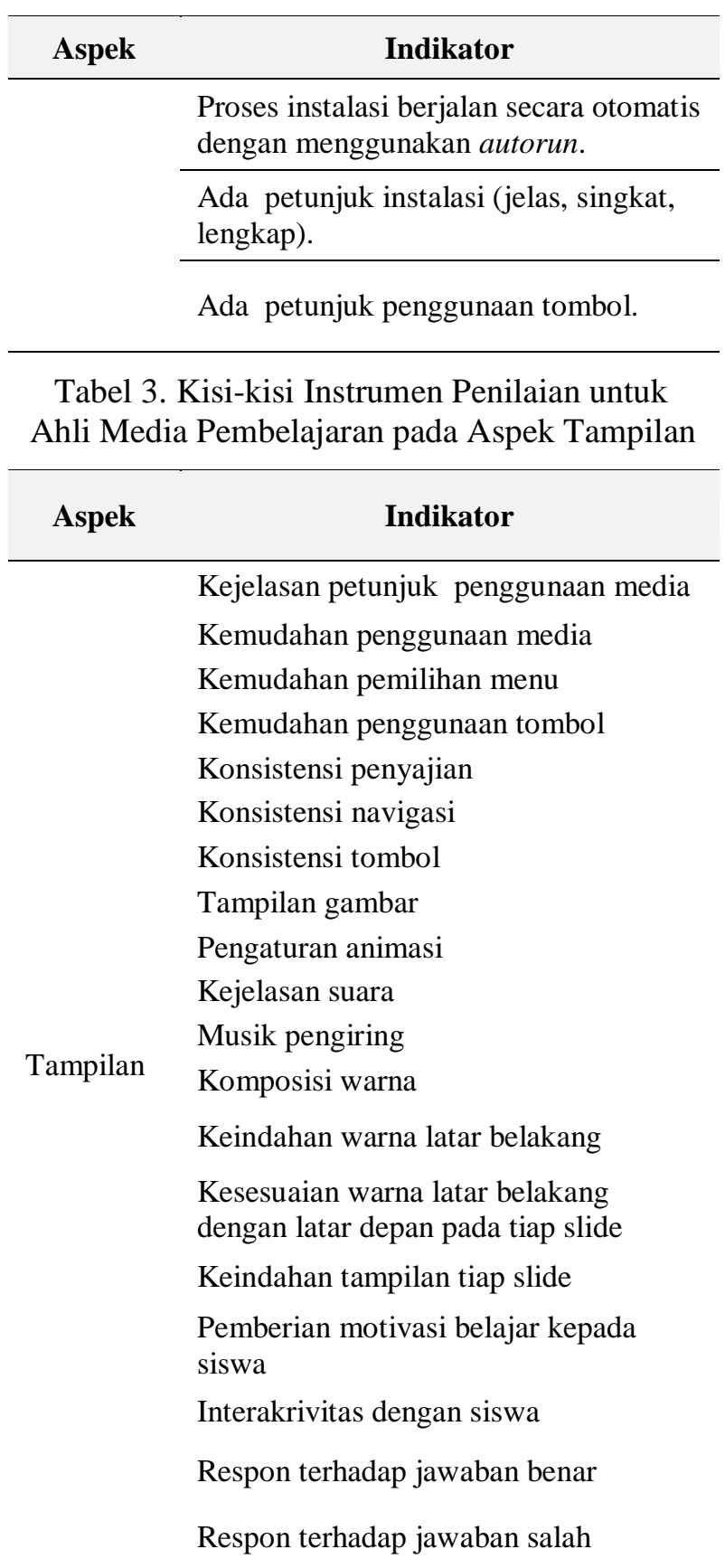

Tes diberikan kepada siswa pada saat uji coba lapangan untuk mengetahui ketuntasan belajar siswa.

\section{Teknik Analisis Data}

Data kuantitatif dianalisis secara deskriptif dengan berpedoman pada tabel konversi skala lima dari Sukardjo (2005, p.53), pedoman konversi dapat dilihat pada Tabel 4 . berikut.
Tabel 4. Konversi Nilai Skala Lima

\begin{tabular}{ccc}
\hline $\begin{array}{c}\text { Data } \\
\text { Kuantitatif }\end{array}$ & Interval & Data Kualitatif \\
\hline 5 & $\mathrm{X}>4,2$ & Sangat baik \\
4 & $3,4<\mathrm{X} \leq 4,2$ & Baik \\
3 & $2,6<\mathrm{X} \leq 3,4$ & Cukup \\
2 & $1,8<\mathrm{X} \leq 2,6$ & Kurang \\
1 & $\mathrm{X} \leq 1,8$ & Sangat kurang \\
\hline
\end{tabular}

Keterangan:

Skor maksimal ideal $=5$

Skor minimal ideal $=1$

$X \mathrm{i}=1 / 2(5+1)=3$

$\mathrm{SBi}=1 / 6(5-1)=0,67$

Data kuantitatif hasil tes juga dijadikan acuan sebagai kelayakan media, media pembelajaran yang dikembangkan ini dinyatakan layak jika jumlah siswa yang mencapai KKM di atas $80 \%$.

\section{HASIL DAN PEMBAHASAN}

Setelah tujuan penelitian dan pengembangan ditetapkan, langkah berikutnya adalah kegiatan prasurvei. Prasurvei dilakukan untuk menganalisis kebutuhan akan media pembelajaran kosakata bahasa Inggris berbantuan komputer. Responden prasurvei ini adalah guru-guru bahasa Inggris SMP di Kota Banjarmasin dan Kabupaten Hulu Sungai Selatan. Hasil prasurvei tersebut dapat dilihat pada Tabel. 5 berikut ini.

Tabel 5. Tanggapan Guru terhadap Perlu atau Tidaknya Media Pembelajaran Kosakata Bahasa Inggris Berbantuan Komputer

\begin{tabular}{ccccc}
\hline Valid & Frequency & Percent & $\begin{array}{c}\text { Valid } \\
\text { Percent }\end{array}$ & $\begin{array}{c}\text { Cumulative } \\
\text { Percent }\end{array}$ \\
\hline Tidak & 184 & 18.3 & 19.0 & 19.0 \\
Ya & 784 & 78.2 & 81.0 & 100.0 \\
Total & 968 & 96.5 & 100.0 & \\
$\begin{array}{c}\text { Missing } \\
\text { System }\end{array}$ & 35 & 3.5 & & \\
Total & 1003 & 100.0 & & \\
\hline
\end{tabular}

Dari Tabel 5. tersebut dapat dilihat data yang valid/sah ada 968, maksudnya adalah data yang ada jawaban sebanyak 968 item, sedangkan data missing ada, 35 maksudnya adalah sebanyak 35 item pertanyaan yang tidak dijawab oleh responden atau mempunyai jawaban ganda. Jawaban "Ya" sebanyak 784 atau 78,2\%, jawaban "Tidak" sebanyak 184 atau 18,3\% saja. Jadi 
dapat disimpulkan bahwa guru-guru membutuhkan media pembelajaran kosakata bahasa Inggris berbantuan komputer.

Setelah selesai melakukan prasurvei untuk analisis kebutuhan, didapatkan kesimpulan bahwa dalam pembelajaran kosakata bahasa Inggris diperlukan media pembelajaran berbantuan komputer yang layak digunakan dalam pembelajaran. Sebagai tindak lanjut dari hasil analisis kebutuhan tersebut, peneliti mengadakan Fokus Group Discussion. Focus Group Discussion ini diadakan untuk mengumpulkan informasi yang dijadikan dasar atau pedoman dalam pembuatan draft materi dan draft media.
Materi dan media didesain berdasarkan hasil dari FGD. Kegiatan dilaksanakan pada hari Rabu tanggal 4 Juli 2012 di Ruang Diskusi 304 PPs Universitas Negeri Yogyakarta dan diikuti oleh enam orang peserta, terdiri dari tiga orang ahli media, dua orang ahli materi, dan satu orang praktisi.

Dari penelitian dan pengembangan yang dilakukan melalui serangkaian langkah-langkah kegiatan, dihasilkan sebuah produk media pembelajaran. Data skor hasil penilaian produk oleh validator dapat dilihat pada Tabel 6, dan hasil tes siswa untuk mengetahui ketuntasan belajar dapat dilihat pada tabel 7 .

Tabel 6. Hasil Total Penilaian Masing-masing Aspek oleh Validator

\begin{tabular}{|c|c|c|c|c|c|c|}
\hline \multirow[b]{2}{*}{ No } & \multirow[b]{2}{*}{ Validator } & \multicolumn{3}{|c|}{ Nilai Rata-rata } & \multirow{2}{*}{$\begin{array}{l}\text { Rata- } \\
\text { rata }\end{array}$} & \multirow[b]{2}{*}{ Kategori } \\
\hline & & $\begin{array}{l}\text { Aspek } \\
\text { Materi }\end{array}$ & $\begin{array}{c}\text { Aspek } \\
\text { Pemrograman }\end{array}$ & $\begin{array}{c}\text { Aspek } \\
\text { Tampilan }\end{array}$ & & \\
\hline 1 & Ahli Materi & 4,00 & - & - & 4,00 & Baik \\
\hline 2 & Ahli Pemrograman & - & 4,21 & - & 4,21 & Sangat Baik \\
\hline 3 & Ahli Tampilan & - & - & 4,42 & 4,42 & Sangat Baik \\
\hline 4 & Guru & 4,75 & - & 4,57 & 4,66 & Sangat Baik \\
\hline 5 & Siswa Uji Coba Perorangan & 4,92 & - & 3,80 & 4,31 & Sangat Baik \\
\hline 6 & Siswa Uji Coba Kelompok Kecil & 4,31 & - & 4,52 & 4,41 & Sangat Baik \\
\hline \multirow[t]{3}{*}{7} & Siswa Uji Coba Lapangan & 4,39 & - & 4,87 & 4,63 & Sangat Baik \\
\hline & Jumlah & 22,37 & 4,21 & 22,18 & 30,64 & Sangat Baik \\
\hline & Rata-rata & 4,47 & 4,21 & 4,44 & 4,38 & Sangat Baik \\
\hline
\end{tabular}

Tabel 6. tersebut menunjukkan bahwa ahli materi memberikan nilai 4 dalam tabel skala lima termasuk kategori "Baik", ahli pemrograman memberikan nilai 4,21 dalam tabel skala lima termasuk kategori "Sangat baik", ahli tampilan memberikan nilai 4,42 dalam tabel skala lima termasuk kategori "Sangat baik", guru memberikan nilai 4,66 dalam tabel skala lima termasuk kategori "Sangat baik", siswa uji coba perorangan memberikan nilai 4,31 dalam tabel skala lima termasuk kategori "Sangat baik", siswa uji coba kelompok kecil memberikan nilai 4,41 dalam tabel skala lima termasuk kategori "Sangat baik", siswa uji coba lapangan memberikan nilai 4,63 dalam tabel skala lima termasuk kategori "Sangat baik". Nilai rata-rata secara keseluruhan adalah 4,38 dalam tabel skala lima termasuk kategori "Sangat baik". Jadi dapat disimpulkan bahwa media pembelajaran kosakata bahasa
Inggris berbantuan komputer yang dikembangkan ini termasuk kategori "Sangat baik", yang berarti bahwa media pembelajaran ini layak digunakan untuk siswa SMP kelas VII.

Tabel 7. Hasil Tes Ketuntasan Belajar Siswa

\begin{tabular}{cccc}
\hline No & Tes & Nilai Rata-rata & Ketuntasan \\
\hline 1 & Pertama & 67,5 & $53 \%$ \\
2 & Kedua & 71,3 & $73 \%$ \\
3 & Ketiga & 78,3 & $100 \%$ \\
\hline
\end{tabular}

Pada Tabel 7. tersebut dapat dilihat hasil tes ketuntasan belajar siswa. Tes pertama dilakukan sebelum menggunakan media berbantuan komputer. Pada tes awal hanya 53\% siswa yang mampu mencapai kriteria ketuntasan minimal (KKM). Setelah dua kali pembelajaran meng- 
gunakan media pembelajaran berbantuan komputer, diadakan tes kedua dengan hasil sebanyak 73\% siswa dapat mencapai KKM. Hasil pembelajaran pertama dan kedua ini sudah cukup baik, tapi belum mencapai target yaitu lebih dari $80 \%$ siswa dapat mencapai KKM. Kendalanya secara umum adalah siswa masih dalam tahap adaptasi terhadap media ini sehingga masih belum fokus pada materi pembelajaran. Diakhir pembelajaran pertemuan keempat diadakan tes ketiga, dengan hasil sangat memuaskan yaitu $100 \%$ atau semua siswa dapa mencapai KKM. Karena dengan menggunakan media pembelajaran kosakata bahasa Inggris berbantuan komputer dapat mencapai target yang telah ditetapkan peneliti, maka dapat disimpulkan bahwa media ini layak digunakan untuk pembelajaran.

\section{SIMPULAN}

Dari penelitian dan pengembangan yang telah dilaksanakan, maka dapat ditarik beberapa simpulan sebagai berikut:

\section{Bentuk Media yang Dihasilkan}

Produk berupa CD pembelajaran kosakata bahasa Inggris berbantuan komputer untuk siswa SMP kelas VII, yang berisi (1) slide pembukaan yang memuat judul, (2) pendahuluan; (3) petunjuk penggunaan; (4) kompetensi yang akan dicapai; (5) materi-materi pembelajaran; (6) latihan soal interaktif yang menarik; (7) soal evaluasi dan skor yang dicapai siswa; (8) animasi, gambar, warna dan suara untuk menarik perhatian dan meningkatkan motivasi siswa; dan (9) profil pengembang.

\section{Produk Media dalam Bentuk Cetakan}

Kelayakan Media

Aspek materi, kelayakan media pada aspek materi dinilai sangat layak dengan skor rata-rata 4,47 pada skala lima.

Aspek pemrograman, kelayakan media pada aspek pemrograman dinilai sangat layak dengan skor rata-rata 4,21 pada skala lima.

Aspek tampilan, kelayakan media pada aspek tampilan dinilai sangat layak dengan skor rata-rata 4,44 pada skala lima.

\section{DAFTAR PUSTAKA}

Alessi, S.M. \& Trollip, S.R. (2001). Multimedia for learning: Method and development $\left(3^{\text {rd }} e d\right.$.). Boston: Allyn and Bacon.

Arief S. Sadiman, R. Rahardjo, Anung Haryono, et al. (2010). Media pendidikan:
Pengertian, pengembangan dan pemanfaatannya. Jakarta: PT Raja Grafindo Persada.

Arsyad, Azhar. (2011). Media pembelajaran. Jakarta: PT. Raja Grafindo Persada.

Borg, W. R. \& Gall, M. D. (1983). Educational research: An introduction ( $4^{\text {th }}$ ed.). New York: Longman, Inc.

Brown, H.D. (2002). Teaching by priciples: An interactive approach to language pedagogy. New York: Longman, Inc.

Cilesiz, S. (2009). Educational computer use in leisure contex: A phenomenological study of adolescents' experience at internet cafes. American Educational Research Journal, 46, pp.232-274.

Constantinescu, A. I. (Februari 2007). Using technology to assist in vocabulary acquisition and reading comprehension. TESL Journal, Vol. XIII, No. 2. Diambil tanggal 7 Agustus 2011, dari http://iteslj.org/Articles/ Constant inescu-Vocabulary. html.

Sulaeman, Dadang. (1988). Teknologi/metodologi pengajaran. Jakarta: Depdik-bud.

Indriana, Dina. (2011). Ragam alat bantu media pengajaran. Yogyakarta: Diva Press.

Egbert, J.L. (2005). Conducting research on call. Dalam J.L. Egbert \& G.M. Petrie (Eds.), Call Research Perspectives (pp.3-8). London: Lawrence Erlbaum Associated.

Bussmann, Hadumod (Ed.). (1996). Roudledge dictionary of language and linguistics. London: Roudledge

Kridalaksana, Harimurti. (2008). Kamus linguistik. Jakarta: Gramedia Pustaka Utama

Heinich, R., Richey, R.C., Owens, D.L., et al. (1996) Instructional media and technologies for learning. New Jersey: Prentice Hall, Englewood Cliffs.

Hornby, A. S. (1984). The Advance learner's dictionary of current english. ( $4^{\text {th }} e d$.). New York: Oxpord University Press.

Hoskisson, K. \& Tompkins, G. E. (1987) Language arts: Content and teaching strategies. Melbourne: Merill Publishing Company. 
Kemp, J. E. \& Dayton, D.K. (1985). Planning and producing instructional media $\left(5^{\text {th }}\right.$ ed). New York: Harper \& Row Publisher Cambridge.

Lado, R. (1979). Language teaching: A scientific approach. New York: TMH Publishing Co LTD.

Lee, W.W. \& Owens, D.L. (2004). Multimediabased instructional design. San Fransisco: Pfeiffer.

Ma, K. \& Kelly, P. (2006). Computer assisted vocabulary learning: Design and evaluation. Journal of Computer Assisted Language Learning, 19, pp.1545.

Mayer, R.E. (2001). Multimedia learning. (Terjemahan Baroto Tavip Indro-jarwo). New York: Cambridge University Press. (Buku asli diterbitkan tahun 2001).

McCarthy, M. \& O’Dell, F. (1999). English vocabulary in use: Upper-intermediate \& advanced. New York: Cambridge University Press.

Misra, S. \& Sharma, R.C. (2005). Interactive multimedia in education and training. London: Idea Group Publishing.

Nana Sudjana \& Ahmad Rivai. (2010). Media pengajaran. Bandung: Sinar Baru Algensindo.

Nation, P. (2002). Best practice in vocabulary teaching and learning. Dalam J.C. Richards \& W.A. Renandya (Eds.), Methodology in Language Teaching: An Anthology of Current Practice (pp.267272). Cambridge: Cambridge University Press.
Nation, P. (2002). Managing vocabulary learning. Singapore: SEAMEO Regional Language Center.

Nunan, D. (1991). Language teaching methodology. New York: Prentice-Hall, Inc.

Richards, J. C. \& Renandya, W. A. (2002). Methodology in language teaching: An anthology of current practice. Cambridge: Cambridge University Press.

Seels, B.B., \& Richey, R.C. (1994). Instructional technology: The definition and domain of the filed. Washington DC: Association for Communication and Technology.

Sukardjo. (2005). Kumpulan materi evaluasi pembelajaran. Diktat pegangan kuliah prodi teknologi pembelajaran, tidak diterbitkan. Universitas Negeri Yogyakarta, Yogyakarta.

Suwarna. (2006). Pengajaran mikro: Pendekatan praktis dalam menyiapkan pendidik professional. Yogyakarta: Tiara Wacana.

Suyanto. (2003). Multimedia: Alat untuk meningkatkan keunggulan bersaing. Yogyakarta: Andi.

Tarigan, H. G. (1986). Pengajaran kosakata. Bandung: Angkasa.

Tchounikine, P. (2011). Computer science and educational software design: A resource for multidisciplinary work in technology enhanced learning. New York: Springer.

Thornbury. S. (2002). How to teach vocabulary. Harlow: Pearson Education Limited. 